\title{
SPECTROPHOTOMETRIC STUDIES OF LOWER OXIDATION STATES OF TECHNETIUM
}

\author{
G. B. S. Salaria, Charles L. Rulfs and Philip J. Elving \\ Department of Chemistry, University of Michigan, Ann Arbor, Michigan, U.S.A.
}

(Received 26 April 1963. Accepted 14 June 1963)

\begin{abstract}
Summary-The spectrophotometric behaviour of lower oxidation states of technetium, obtained by reducing pertechnetate under different conditions by various methods, has been examined. Contrary to some of the previously advanced conclusions regarding the ascorbic acid reduction of pertechnetate, it was found that the technetium is reduced to a quadrivalent state. The latter product does not appear to involve a tightly-bound ascorbate species; neither does it significantly react or complex with $\alpha$-picolinic acid to give a new species.
\end{abstract}

THE lower oxidation states of technetium resulting from chemical or electrochemical reduction of technetium ${ }^{\mathrm{VII}}$, present as pertechnetate in solution, have not been clearly defined for a variety of reactions. ${ }^{1}$ Surveys of the polarographic reduction patterns of technetium ${ }^{\text {II }}$ solutions, ${ }^{2,3}$ supplemented by more detailed studies, ${ }^{4-6}$ begin to decrease the uncertainties involved in characterising the lower oxidation levels.

Spectrophotometric data should provide further information regarding the technetium species involved, but the data so far reported are limited and somewhat contradictory. The absorption spectrum of pertechnetate ion is well $\mathrm{known}^{7,8}$ and a technetium ${ }^{\mathrm{V}}$-thiocyanate system has been carefully characterised. ${ }^{9}$ Spectra have also been given for technetium ${ }^{\mathrm{IV}}$ and technetium ${ }^{\mathrm{III}}{ }^{111}$ and undefined lower states, ${ }^{10}$ sometimes over very narrow ranges of wavelength and for unspecified concentrations.

The present paper presents additional data relating to the spectrophotometry of technetium ter- and quadrivalent states. Based on evidence now available, a reinterpretation is suggested for the technetium $\mathrm{V}, \mathrm{VI}_{-} \alpha$-picolinate spectrophotometric method. ${ }^{10}$

\section{Apparatus}

\section{EXPERIMENTAL}

A Beckman Model 2400 DU instrument was used with 1.000-cm quartz cells for the spectrophotcmetric measurements. Polarographic measurements were made with a Fisher Elecdropode and an H-cell thermostatically controlled at $25 \cdot 0 \pm 0 \cdot 1^{\circ}$; one leg of the cell contained a saturated calomel electrode (S.C.E.). pH was measured with a Leeds and Northrup No. $7664 \mathrm{pH}$ meter.

\section{Reagents}

Technetium solutions: A solution of ammonium pertechnetate in water ( $\mathrm{pH} 4$ ) containing $46.75 \mathrm{mg}$ of ${ }^{99} \mathrm{Tc} / \mathrm{ml}$ and $3 \times 10^{-6} \mathrm{mc}$ of ${ }^{95 \mathrm{~m}} \mathrm{Tc} / \mathrm{g}$ of ${ }^{99} \mathrm{Tc}$ was obtained from the Oak Ridge National Laboratory; coulometric studies substantiate the stated concentration. ${ }^{4,5}$ Fertechnetate stock solution I was prepared by diluting $10 \mathrm{ml}$ of this solution to $250 \mathrm{ml} ; 10 \mathrm{ml}$ of solution I were further diluted to $100 \mathrm{ml}$ to give stock solution II (technetium concentration: $1.89 \mathrm{mM}$ ).

Ascorbic acid, $\alpha$-picolinic acid and sulphosalicylic acid solutions: $10 \% \mathrm{w} / \mathrm{v}$ aqueous solutions were prepared from reagent-grade chemicals (ascorbic acid was U.S.P.).

Tin ${ }^{\mathrm{II}}$ chloride solution: $20 \mathrm{~g}$ of $\mathrm{SnCl}_{2} \cdot 2 \mathrm{H}_{2} \mathrm{O}$ were dissolved in $6 M$ hydrochloric acid with warming, then diluted to $100 \mathrm{ml}$ with the same acid. 
Nitrogen: Oil-pumped and used without further purification for purging all solutions of oxygen.

Buffer solutions: A pH 1 buffer solution was prepared by diluting to $200 \mathrm{ml}$ a mixture of $97 \mathrm{ml}$ of $0.2 \mathrm{M}$ hydrochloric acid and $2.983 \mathrm{~g}$ of potassium chloride. A pH 2 buffer solution was prepared by diluting to $500 \mathrm{ml}$ a mixture of $26.5 \mathrm{ml}$ of $0.2 \mathrm{M}$ hydrochloric acid and $125 \mathrm{ml}$ of $0.2 \mathrm{M}$ potassium chloride. The measured $\mathrm{pH}$ values of these buffer solutions were $1 \cdot 0$ and $2 \cdot 0$, respectively.

All other chemicals used were C.P. grade.

\section{Polarographic procedure}

Twenty-five $\mathrm{ml}$ of pertechnetate solution II and $25 \mathrm{ml}$ of ascorbic acid solution were diluted to volume in a $250-\mathrm{ml}$ volumetric flask with $\mathrm{pH} 2$ buffer. About $15-\mathrm{ml}$ portions of this solution (tcchnetium $^{\text {VII }}$ concentration $0.189 \mathrm{mM}$ ) were transferred to the H-cell at different intervals of time after preparation of the solution, deoxygenated with nitrogen for 10 to $15 \mathrm{~min}$, then polarographed over the potential range of 0.0 to $-1.5 \mathrm{~V} v$ s. S.C.E. $E_{\frac{1}{z}}$ and $i_{d}$ were determined graphically, utilising the maximum deflections.

\section{Spectrophotometric procedures}

(1) In a 10-ml volumetric flask, $0.5 \mathrm{ml}$ of pertechnetate solution II was well mixed with $5 \mathrm{ml}$ of $\mathrm{pH} 2$ buffer and $1 \mathrm{ml}$ of ascorbic acid solution, heated at $\mathrm{ca} .70^{\circ}$ under an infrared lamp for $20 \mathrm{~min}$, cooled and diluted to volume with $\mathrm{pH} 2$ buffer; the spectrum of the resulting solution was measured at different intervals of time against a biank containing $1 \mathrm{ml}$ of ascorbic acid solution diluted to $10 \mathrm{ml}$ with $\mathrm{pH} 2$ buffer. This procedure was also used with $0.5 \mathrm{ml}$ of $\alpha$-picolinic acid solution present in addition to the ascorbic acid.

(2) In a $10-\mathrm{ml}$ volumetric flask, $0.5 \mathrm{ml}$ of pertechnetate solution II was thoroughly mixed with $4 \mathrm{ml}$ of $\mathrm{pH} 1$ buffer solution and $0.2 \mathrm{ml}$ of tin II chloride solution, then diluted to volume with $\mathrm{pH} 1$ buffer. The absorption spectrum was measured against a blank containing $0.2 \mathrm{ml}$ of $\operatorname{tin}^{\mathrm{II}}$ chloride solution diluted to $10 \mathrm{ml}$ with $\mathrm{pH} 1$ buffer. A similar procedure was employed with the addition of $1 \mathrm{ml}$ of sulphosalicylic acid solution in addition to the $\mathrm{tin}^{\mathrm{II}}$ chloride.

\section{RESULTS AND DISCUSSION}

Al-Kayssi, Magee and Wilson ${ }^{10}$ reduced technetium ${ }^{\mathrm{VII}}$ in hydrochloric acid solution with either tin ${ }^{\text {II }}$ chloride or ascorbic acid to give a postulated quadri- or quinquevalent state complex with $\alpha$-picolinic acid; the resulting pink solution showed a molar absorptivity ( $\epsilon$ ) of about 4,400 at $480 \mathrm{~m} \mu$.

On treating pertechnetate with ascorbic acid by the same method ${ }^{10}$ but in the absence of $\alpha$-picolinic acid, reduction occurs very slowly ( $c f$. Table I) with the molar

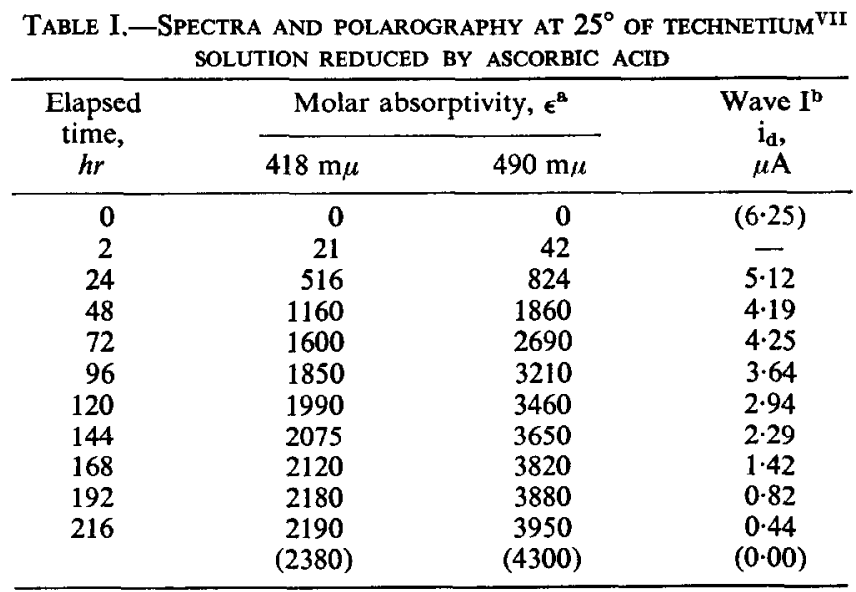

"Solution was $0.095 \mathrm{mM}$ in technetium; a complete spectrophotometric run took about $30 \mathrm{~min}$.

$\mathrm{b} \mathrm{E}_{1}$ was between -0.150 and $-0.158 \mathrm{~V} v$ s. S.C.E; the value of 6.25 $\mu \mathrm{A}$ is the current obtained for a similar technetium solution in the absence of ascorbic acid. 
absorptivities finally approaching 4,300 at $485 \mathrm{~m} \mu$ (maximum) and 2,380 at $418 \mathrm{~m} \mu$ (minimum). The prior or subsequent addition of $\alpha$-picolinic acid in this procedure results in no change in the position or intensity of these absorption characteristics (curve A of Fig. 1).

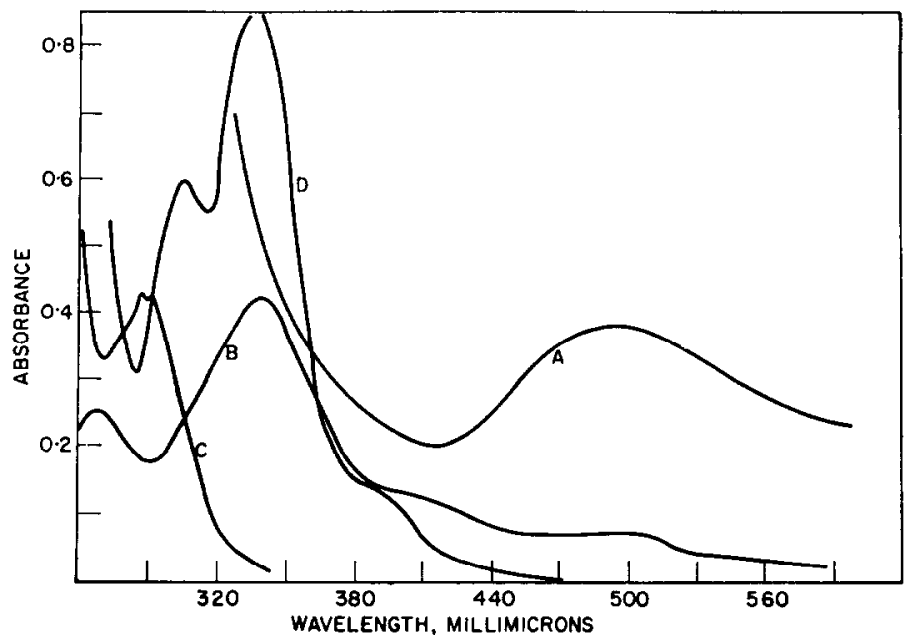

FIG. 1.-Absorption spectra:

(A) $0.095 \mathrm{mM}$ technetium ${ }^{\mathrm{IV}}$ solution resulting from ascorbic acid reduction;

(B) partially re-oxidised technetium ${ }^{\mathrm{III}}$ via coulometry $\left(56 \%\right.$ technetium $^{\mathrm{VII}}$ and $44 \%$ technetium ${ }^{\mathrm{III}}$ ) equivalent to $0.090 \mathrm{mM}$

(C) $0.095 \mathrm{~m} M$ pertechnetate ion;

(D) $0.189 \mathrm{~m} M\left(\mathrm{TeCl}_{6}\right)^{2-}$ ion.

The rate of decrease in the first polarographic reduction wave of pertechnetate ${ }^{4,5}$ in the presence of ascorbic acid is in agreement with the increase in molar absorptivity. The half-wave potential of this wave, which represents the reduction of technetium ${ }^{\text {VII }}$ to technetium III, is not significantly shifted by the presence of the ascorbic acid; the slope is also unchanged. While this wave does shift in the expected manner ${ }^{4}$ as a function of $\mathrm{pH}$, it is irreversible (slope criterion) and its failure to shift here is not incontrovertible evidence of the non-existence of ascorbate complexes of the reduced technetium state or states.

The partial extraction by chloroform of the "quadri- or quinquevalent $\alpha$-picolinate complex" of technetium has been noted. ${ }^{10}$ In the present study, the red solutions obtained by the reduction of pertechnetate with ascorbic acid were made $0.05-6 M$ in sulphuric acid and extracted with equal volumes of chloroform. Radiometric assay of the two layers indicated an extraction of $2 \cdot 5-5 \cdot 5 \%$, corresponding to a low distribution coefficient of $0 \cdot 03-0 \cdot 06$. Better extraction of technetium ${ }^{\mathrm{IV}}$, for example, is obtained with ether from $0 \cdot 0-6 M$ hydrochloric acid solution. However, these results correspond to distribution coefficients of less than $0 \cdot 1$, and are not indicative of the existence of significant amounts of organic solvent soluble technetium-ascorbate species.

In order to ascertain whether the ascorbate-reduced solution contained any technetium III, a yellow-green technetium ${ }^{\text {III }}$ solution, prepared by the macroscale reduction at a mercury cathode of an acidic pertechnetate solution, ${ }^{5}$ was rapidly examined spectrophotometrically after dilution. (The spectrum obtained had nothing 
in common with that observed for technetium ${ }^{\mathrm{III}}$ in $\mathrm{pH} 7$ phosphate solution between 400 and $750 \mathrm{~m} \mu .^{6}$ ) The appreciable amount of technetium ${ }^{\mathrm{VII}}$, which developed as a result of rapid air oxidation, was determined polarographically and the spectrophotometric curve was corrected by subtracting the absorbance from technetium ${ }^{\mathrm{VII}}$ to give curve B of Fig. 1; inaccuracies in this correction, from the presence of technetium ${ }^{\mathrm{IV}}$ or technetium ${ }^{\mathrm{V}}$, may account for the apparent features at 270 and $290 \mathrm{~m} \mu$; however, the peak at $340 \mathrm{~m} \mu$ is essentially free of any effects from technetium ${ }^{\mathrm{VII}}$.

Based on the absence in the ascorbate-reduced solution (curve A of Fig. 1) of the 340-m $\mu$ peak observed in the technetium solution, it can be safely asserted that the ascorbate-reduced solution does not contain appreciable amounts of technetium ${ }^{\mathrm{III}}$; this is confirmed by the presence in the ascorbate-reduced solution of an absorption maximum at $485 \mathrm{~m} \mu$ which is absent in the technetium ${ }^{\mathrm{III}}$ solution.

The nature of the technetium ${ }^{\mathrm{IV}}$ species obtained by ascorbate reduction, as indicated by its spectrum (curve A of Fig. 1), is different from the technetium ${ }^{\mathrm{IV}}$ species obtained by reduction in hydrochloric acid (curve D of Fig. 1). The latter spectrum is that of pertechnetate, which was allowed to stand for about 1 month in $9 M$ hydrochloric acid, then examined against a blank of $9 M$ hydrochloric acid; the molar absorptivity of 9,100 at $338 \mathrm{~m} \mu$ is in general agreement with the value of 11000 , reported for spectrophotometry in $1 M$ hydrochloric acid after reduction in $9 M$ hydrochloric acid. ${ }^{11}$

Consequently, it may be concluded that ascorbic acid, in the absence of thiocyanate, reduces pertechnetate very slowly to a technetium ${ }^{\mathrm{IV}}$ species, which shows a maximum at $485 \mathrm{~m} \mu$ with a molar absorptivity of 4,300 to 4,400 as previously reported. ${ }^{10}$ The red colour of the technetium ${ }^{\mathrm{IV}}$ species and the absence of a precipitate of technetium dioxide suggests the formation of an ascorbate complex, but the polarographic behaviour of the partially reduced solution is contrary to such a postulation, i.e., formation of a technetium ${ }^{\mathrm{IV}}$-ascorbate complex should involve a shift in $E_{1}$, which does not occur.

Miller et al..$^{6}$ coulometrically reduced technetium ${ }^{\mathrm{VII}}$ in $\mathrm{pH} 7$ phosphate buffer to a pink quadrivalent state, which absorbed at $515 \mathrm{~m} \mu$ with an $\epsilon$ of 380 . Apparently, the technetium ${ }^{\mathrm{IV}}$ forms a stable red-coloured complex as indicated by the shift of the absorption maximum from 485 to $515 \mathrm{~m} \mu$ and the decrease in molar absorptivity from 4,300 to 380 . Similar pink or pale-violet solutions were obtained by the present authors after coulometric reduction of technetium to a quadrivalent state in noncomplexing acidic media. ${ }^{4,5}$

Reduction of $0.189 \mathrm{~m} M$ pertechnetate in $0.1 M$ hydrochloric acid by tin ${ }^{\mathrm{II}}$ chloride, which is complete in about $30 \mathrm{~min}$, gives an orange-coloured solution (maximum at $445 \mathrm{~m} \mu, \epsilon=670$ ). Polarography of this solution does not show any portion of the wave from the reduction of technetium ${ }^{\mathrm{VII}}$ to technetium ${ }^{\mathrm{III}}\left(\mathrm{E}_{1}=+0.02 \mathrm{~V} v\right.$ s. S.C. E.). The polarographic wave, which does appear at $E_{\frac{1}{2}}$ of $-0.41 \mathrm{~V} v$ s. S.C.E., is that from the reduction of tin II; however, the current is $224 \mu \mathrm{A}$, compared to $206 \mu \mathrm{A}$ observed for tin ${ }^{\mathrm{II}}$ alone. The increase may be caused by reduction of $\operatorname{tin}^{\mathrm{IV}}$ formed and to further reduction of technetium to the metal (the reduction of technetium III to technetium ${ }^{0}$ normally occurs at $\mathrm{E}_{\frac{1}{2}}$ of $c a .-0.9 \mathrm{~V}$ at the acidity involved).

Reduction of pertechnetate in $0.1 \mathrm{M}$ hydrochloric acid by tin ${ }^{\mathrm{II}}$ chloride in the presence of sulphosalicylic acid gives in $30 \mathrm{~min}$ a solution having an absorption maximum at $430 \mathrm{~m} \mu$ of $\epsilon=1120$. The changes in absorption would indicate formation 
of a sulphosalicylate complex by the reduced technetium. Earlier workers ${ }^{10}$ have reported for a similar operation a maximum at $460-470 \mathrm{~m} \mu$, without mentioning the

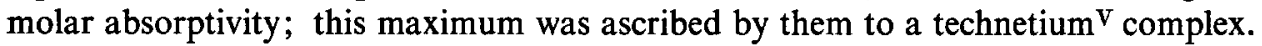

Acknowledgments-One of the authors (G. B. S. S.) wishes to thank the National Academy of Sciences (U.S.A.) for an appointment supported by the International Cooperation Administration under the Visiting Research Scientist Program.

\begin{abstract}
Zusammenfassung-Das spektralphotometrische Verhalten durch Reduktion von Pertechnetat unter verschiedenen Bedingungen und nach verschiedenen Methoden erhaltener niedriger Oxydationsstufen von Tc wurde untersucht. Im Gegensatz zu einigen früher gezogenen Folgerungen über die Reduktion von Pertechnetat mit Ascorbinsäure wurde gefunden, $\mathrm{da} \beta \mathrm{Tc}$ zur vierwertigen Stufe reduziert wird. Das Produkt enthält offenbar kein Ascorbat fest gebunden; auch reagiert es nicht nennenswert mit $\alpha$-Picolinsäure zu einer neuen Verbindung.
\end{abstract}

\begin{abstract}
Résumé-On examine le comportement spectrophotométrique de l'état inférieur d'oxydation du technetium, obtenu par réduction du pertechnetate dans différentes conditions et par diverses méthodes. Contrairement à de nombreuses conclusions antérieures, la réduction du pertechnetate par l'acide ascorbique, il a pu être montré que le technétium est réduit à l'état d'oxydation (IV). Ce dernier ne semble pas être fortement lié aux molécules d'acide ascorbique et ne réagit pas, d'une manière caractéristique, ni ne fournit de complexe avec l'acide $\alpha$-picolinique.
\end{abstract}

\title{
REFERENCES
}

${ }^{1}$ E. Anders, The Radiochemistry of Technetium, U.S. Atomic Energy Commission, Bulletin NASNRC 3021, Washington, 1960.

${ }^{2}$ R. Colton, J. Dalziel, W. P. Griffith and G. Wilkinson, J. Chem. Soc., 1960, 71.

${ }^{3}$ R. J. Magee, I. A. P. Scott and C. L. Wilson, Talanta, 1959, 2, 376.

${ }^{4}$ G. B. S. Salaria, C. L. Rulfs and P. J. Elving, J. Chem. Soc., 1963, 2479.

${ }^{5}$ Idem, Analyt. Chem., 1963, 35, 979.

- H. H. Miller, M. T. Kelley and P. F. Thomason, in I. S. Longmuir, ed., Advances in Polarography. Pergamon Press, London, 1960, Vol. 2, pp. 716-26.

${ }^{7}$ C. L. Rulfs and W. W. Meinke, J. Amer. Chem. Soc., 1952, 74, 235, 6313.

${ }^{8}$ G. E. Boyd, J. W. Cobble, C. M. Nelson and W. T. Smith, ibid., 1952, 74, 556.

${ }^{\circ}$ C. E. Crouthamel, Analyt. Chem., 1957, 29, 1756.

${ }^{10}$ M. Al-Kayssi, R. J. Magee and C. L. Wilson, Talanta, 1962, 9, 125.

${ }^{11}$ R. J. Busey, U.S. Atomic Energy Commission, Document ORNL-2782, 1959. 